\title{
Evaluation of arugula cultivars and seed production in the organic system ${ }^{1}$
}

\author{
Patricia Augusto da Silva ${ }^{2 *}$ (D), Sakae Kinjo ${ }^{2}$ (D), \\ Marcia Provinzano Braga Xavier de Melo $^{2}$ iD, Fernando César Sala ${ }^{3}$
}

\begin{abstract}
The production of arugula (Eruca sativa Mill.) in Brazil uses seeds produced in the conventional system, without availability of organic seeds. The aim of this research was to indicate the cultivars of arugula with best performance for commercial production and to evaluate seed production viability, as well as seed quality of these cultivars in the organic production system. Eight cultivars were evaluated in a protected environment for agronomic characteristics in two periods and for seed production. The parameters evaluated were plant height, number of leaves, shoot fresh and dry weight, yield, iron and vitamin $\mathrm{C}$ contents. For seed production, time for flowering, number of branches per plant, silique length, number of siliquae per plant, number of seeds per silique, yield, one thousand seed weight, first count of germination, germination and seed health. After storage, first germination count, germination, seedling emergence, emergence speed index and seed health were evaluated. "Astro" and "Giovana" performed well in the organic system. Organic arugula seeds can be produced with high yield and good seed quality in a protected environment, and the cultivars Astro and LG Maia are suitable for this purpose.
\end{abstract}

Index terms: Eruca sativa Mill., growing seasons, agronomic performance, seed yield, storage.

\section{Avaliação de cultivares de rúcula e produção de sementes no sistema de cultivo orgânico}

\begin{abstract}
RESUMO - A produção de rúcula (Eruca sativa Mill.) no Brasil utiliza sementes produzidas pelo sistema convencional, não tendo disponibilidade de sementes orgânicas. O objetivo deste trabalho foi indicar as cultivares de rúcula de melhor desempenho durante a fase de produto comercial e avaliar a viabilidade da produção de sementes, assim como a germinação, vigor e sanidade, em sistema orgânico. Avaliaram-se oito cultivares, em ambiente protegido, para características agronômicas em dois períodos e produção de semente. Os parâmetros avaliados foram altura de planta, número de folhas, massa fresca e seca da parte aérea, rendimento, teor de ferro e vitamina C. Para a produção de sementes, avaliaram-se tempo para florescimento, número de ramificações por planta, comprimento de síliquas, número de síliquas por planta, número de sementes por síliqua, rendimento, massa de mil sementes, primeira contagem de germinação, germinação e sanidade. Após o armazenamento, avaliaram-se a primeira contagem de germinação, a germinação, a emergência de plântulas, o índice de velocidade de emergência e a sanidade de sementes. As cultivares "Astro" e "Giovana" apresentam bom desempenho produtivo no sistema orgânico. É possível produzir sementes orgânicas de rúcula com alto rendimento, germinação e sanidade em ambiente protegido. As cultivares Astro e LG Maia se destacam na produção de sementes com elevada germinação, vigor e sanidade, em sistema orgânico.
\end{abstract}

Termos para indexação: Eruca sativa Mill., épocas de cultivo, desempenho agronômico, rendimento de sementes, armazenamento.

\section{Introduction}

Arugula, which belongs to the family Brassicaceae and is native to the Mediterranean, is a much-appreciated leafy vegetable, consumed in the form of salad, rich in vitamin $\mathrm{C}$, potassium, sulfur and iron, and grown in various regions of Brazil (Filgueira, 2008).

There are 2,756 arugula growers in the organic system registered in Brazil (MAPA, 2018); however, the seeds used by these growers are produced in the conventional system,
${ }^{1}$ Submitted on 1/29/2019. Accepted for publication on 10/11/2019.

${ }^{2}$ Korin Agricultura e Meio Ambiente, Caixa Postal 33, 13537000 - Ipeúna, SP, Brasil.
${ }^{3}$ Departamento de Biotecnologia e Produção Vegetal e Animal, CCA/ UFSCar, 13600970 - Araras, SP, Brasil.

*Corresponding author < patricia.silva@korinagricultura.com.br> 
not in the organic system. Organic seeds increase production costs because they are more expensive, since the options are either imported seeds - whose price in Brazil is $20 \%$ higher than that of conventional seeds (Nascimento, 2013) - or seeds produced in Brazil, whose yield is insufficient to meet the demands of producers.

Seed companies in Brazil do not invest in organic seed production because the use of organic seeds is non-mandatory and there is a low demand for this sector, as a result of the higher cost of seeds. Moreover, there is little research on seed production in this cultivation system.

Producing organic seeds needs further development of technologies adapted to the conditions of Brazil, especially to ensure germination and health, in addition to identifying the most appropriate germplasm, with good commercial characteristics and resistance to pests and diseases (Nascimento, 2013).

Despite the low supply of organic seeds on the market, the cultivation of organic vegetables is on the rise, demonstrating market potential for this type of seed. Vegetable breeding programs for organic cultivation are scarce in Brazil, and conventional cultivars are the only options available to farmers. Therefore, evaluating the performance of cultivars in the organic system is important to check for their agronomic characteristics, as well as their potential for seed production. The aim of this work was to indicate the best performing arugula cultivars during the commercial production phase and to evaluate the viability of producing seeds with high germination rates, vigor and health in an organic system.

\section{Material and Methods}

Two assays were carried out: the first one evaluated the agronomic performance of eight arugula cultivars in the organic system in two growing periods (summer and fall) and the second assay evaluated the same cultivars for seed production in the organic system in the fall. Both tests were performed in the experimental field of the Mokiti Okada Research Center in a protected environment (without closing the sides). The farm is located in Ipeúna, SP, with latitude $22^{\circ} 26^{\prime} 09^{\prime \prime}$ south and longitude $47^{\circ} 43^{\prime} 08^{\prime \prime}$ west and altitude of $635 \mathrm{~m}$.

The soil was classified as a red yellow latosol (EMBRAPA, 2006), with the following chemical characteristics (0-0.2 m); first test: P (mg.dm $\left.{ }^{-3}\right)$ 142; O.M. $\left(\mathrm{g} . \mathrm{dm}^{-3}\right)$ 37; $\mathrm{pH}\left(\mathrm{CaCl}_{2}\right)$ 5.3; $\mathrm{K}\left(\right.$ mmolc. $\left.\mathrm{dm}^{-3}\right)$ 29.7; $\mathrm{Ca}$ $\left(\mathrm{mmolc} . \mathrm{dm}^{-3}\right)$ 56; $\mathrm{Mg}\left(\right.$ mmolc. $\left.\mathrm{dm}^{3}\right)$ 31; S $\left(\right.$ mmolc. $\left.\mathrm{dm}^{-3}\right)$ 14; $\mathrm{H}+\mathrm{Al}\left(\right.$ mmolc. $\left.\mathrm{dm}^{-3}\right)$ 18; $\mathrm{Al}\left(\right.$ mmolc. $\left.\mathrm{dm}^{-3}\right)$ 0.2; SB (mmolc. $\left.\mathrm{dm}^{-3}\right)$ 117; CEC (mmolc.dm $\left.{ }^{-3}\right)$ 135; V (\%) 87; B (mg.dm $\left.{ }^{-3}\right)$
0.4; $\mathrm{Cu}\left(\mathrm{mg} \cdot \mathrm{dm}^{-3}\right)$ 13.0; Fe (mg.dm $\left.{ }^{-3}\right)$ 11.0; $\mathrm{Mn}\left(\mathrm{mg} \cdot \mathrm{dm}^{-3}\right)$ : 19.6; $\mathrm{Zn}\left(\mathrm{mg}^{\left.-\mathrm{dm}^{-3}\right)}\right.$ 3.0; and second test: $\mathrm{P}\left(\mathrm{mg}^{\left.-\mathrm{dm}^{-3}\right)} 204\right.$; O.M. $\left(\mathrm{g} . \mathrm{dm}^{-3}\right) 29 ; \mathrm{pH}\left(\mathrm{CaCl}_{2}\right)$ 5.2; K (mmolc. $\left.\mathrm{dm}^{-3}\right) 28.7 ; \mathrm{Ca}$ $\left(\right.$ mmolc. $\left.\mathrm{dm}^{-3}\right)$ 43; $\mathrm{Mg}\left(\right.$ mmolc.dm $\left.{ }^{-3}\right) 5 ; \mathrm{S}\left(\right.$ mmolc. $\left.\mathrm{dm}^{-3}\right)$ ) $; \mathrm{H}+$ $\mathrm{Al}\left(\right.$ mmolc. $\left.\mathrm{dm}^{-3}\right)$ 12; $\mathrm{Al}\left(\right.$ mmolc. $\left.\mathrm{dm}^{-3}\right)$ 0.2; $\mathrm{SB}\left(\right.$ mmolc. $\left.\mathrm{dm}^{-3}\right)$ 77.1; CEC (mmolc.dm $\left.{ }^{-3}\right)$ 90.1; V (\%) 86; B (mg.dm $\left.{ }^{-3}\right)$ 0.19;

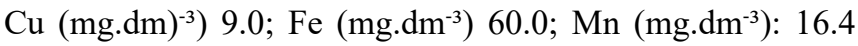
and $\mathrm{Zn}\left(\mathrm{mg} . \mathrm{dm}^{-3}\right) 2.7$.

First assay: The experiment used a randomized block design with eight cultivars (Ágatha, Astro, Apreciatta Folha Larga, Giovana, Folha Larga, Cultivada, Rococó and LG Maia) and eight replications. The soil was prepared with the aid of a tiller and the incorporation of Bokashi fertilizer (100 $\mathrm{gm}^{-2}$ ). Sowing was carried out on January $25^{\text {th }}, 2017$ (summer) and April 26 ${ }^{\text {th }}, 2017$ (fall), in four cultivation rows $(0.30 \mathrm{~m}$ between them), keeping one plant every $0.15 \mathrm{~m}$. Harvesting and evaluations were performed at 37 days after sowing (DAS) in the summer and at 43 DAS in the fall. Ten plants were evaluated in the two central rows per plot and the other rows were considered as borders. The parameters evaluated were plant height $(\mathrm{cm})$ : determined by measuring from the root collar to the end of the largest leaf of each plant; number of leaves per plant: the number of leaves (greater than 0.05 m) was counted; shoot fresh weight (g.plant $\left.{ }^{1}\right)$ : weighing the set of five plants; shoot dry weight (g.plant $\left.{ }^{1}\right)$ : determined after drying the shoot in a forced air circulation oven $\left(70{ }^{\circ} \mathrm{C}\right)$

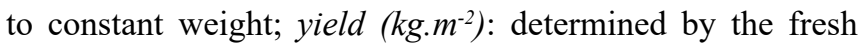
weight of the evaluated shoot divided by the occupied area of each plant; iron content: $100 \mathrm{~g}$ of leaves from four plots were collected and the methodology of Nogueira (2005) was used; vitamin C content: $100 \mathrm{~g}$ of leaves from four plots were collected and analyzed according to the methodology of Carvalho et al. (1990).

Second assay: The experimental design, cultivars and tillage were the same adopted in the first test, and planting was performed in the fall. Spacing was $0.2 \mathrm{~m}$ (plant) and $0.4 \mathrm{~m}$ (rows). Number of days for flowering, determined from sowing until approximately $50 \%$ of the plants were in the flowering stage and expressed in DAS. The seeds were harvested from the ten central plants of each plot, when more than $50 \%$ of the siliquae of the plant were light brown; after that, the number of branches per plant was determined from shoots originating from the main stem; silique length $(\mathrm{cm})$ : six randomized siliquae of each plant were analyzed; total number of siliquae per plant: determined by counting all the siliquae in the plant; number of seeds per silique: performed by counting the seeds of six siliquae of each plant of the plot; seed yield in t.ha ${ }^{-1}$; one thousand seed weight: determined according to Brasil (2009); first germination count and 
germination test: performed according to Brasil (2009), using four replications of a hundred seeds with the results expressed as percentage of normal seedlings per cultivar; health test (fungal incidence): performed by the filter paper method with frozen samples, with four replications of fifty seeds left in incubation chamber for 24 hours at $20 \pm 2{ }^{\circ} \mathrm{C}$ and $12 \mathrm{~h}$ photoperiod. After this period, the seeds were kept at $-20{ }^{\circ} \mathrm{C}$ (freezer) for 24 hours and then transferred to the incubation chamber for a further seven days. The evaluation was performed at the end of this incubation period (Brasil, 2009). The results were expressed as percentage of seeds with incidence of different potentially pathogenic fungi.

Water content was also determined for standardization by the oven drying method $\left(105 \pm 3{ }^{\circ} \mathrm{C}\right.$ for 24 hours) (Brasil, 2009) and the results were expressed as a percentage.

The remaining seeds were placed in paper bags and stored in a cold chamber at $10{ }^{\circ} \mathrm{C}$ and $40 \%$ humidity for one year. After this period, the evaluations of germination, first germination count and seed health (fungal incidence) were repeated. The following tests were also performed: seedling emergence and emergence speed index (ESI).

The emergence test was performed with four replications of fifty seeds in plastic trays with the Plant Bokashi substrate, in a protected environment, with intermittent and automatic micro-sprinkler irrigation. The number of normal seedlings emerged daily until emergence stabilization - which occurred ten days after sowing - was calculated, and ESI was calculated using the formula proposed by Maguire (1962). At the end, the total number of emerged normal seedlings was counted, and the results were expressed as a percentage.

The data were submitted to analysis of variance, and the means were compared by the Scott Knott test at 5\% probability.

\section{Results and Discussion}

In the first assay, in the summer, there was a difference in the number of leaves (NL) and shoot dry weight (SDW) among the cultivars, with Agatha, Astro, Folha Larga, Giovana and LG Maia having the highest values, which did not differ from one another (Table 1). Cultivars with more leaves per plant are more suitable because they are more commonly sold in the form of bunches. These cultivars stood out in the fall for the number of leaves per plant, except for LG Maia, demonstrating the stability of these cultivars in the growing season (Table 1).

Ágatha, Astro and Giovana cultivars presented higher plant height values in the summer and autumn (Table 1). However, it is noteworthy that two plants can be used per hole, with similar results for plant height, thus increasing bunch yield, as found by Reghin et al. (2005), who tested the cultivar "Cultivada".

There were no statistical differences in yield $(\mathrm{Y})$ between cultivars in summer and fall crops, as well as shoot fresh weight (SFW) (Table 1). Plants with a larger number of leaves are expected to have higher yield per plant and area, but this was not found in this work. This may be explained by the plant architecture of each cultivar, which was different from one another. However, the average value is within commercial standards, when the results reported above are compared with those of the organic system and even with the conventional system, as found by Oliveira et al. (2010), who studied the

Table 1. Number of leaves per plant (NL), plant height (PH), shoot fresh weight (SFW), yield (Y), shoot dry weight (SDW) in arugula cultivars produced in a protected organic system in summer and autumn crops.

\begin{tabular}{cccccccccccc}
\hline \multirow{2}{*}{ Cultivar } & \multicolumn{3}{c}{ NL } & \multicolumn{2}{c}{ PH $(\mathrm{cm})$} & \multicolumn{2}{c}{ SFW $\left(\right.$ g.plant $\left.^{-1}\right)$} & \multicolumn{2}{c}{ Y $\left.(\mathrm{kg} . \mathrm{m})^{-2}\right)$} & \multicolumn{2}{c}{ SDW $(\mathrm{g}$. plant } \\
& \cline { 2 - 11 } & Summer & Fall & Summer & Fall & Summer & Fall & Summer & Fall & Summer & Fall \\
\hline Ágatha & $8.4 \mathrm{a}$ & $9.1 \mathrm{a}$ & $30.3 \mathrm{a}$ & $30.4 \mathrm{a}$ & $42.9 \mathrm{a}$ & $33.1 \mathrm{a}$ & $1.11 \mathrm{a}$ & $0.82 \mathrm{a}$ & $2.50 \mathrm{a}$ & $2.02 \mathrm{a}$ \\
Apreciatta Folha Larga & $6.9 \mathrm{~b}$ & $7.5 \mathrm{c}$ & $27.5 \mathrm{~b}$ & $27.7 \mathrm{c}$ & $36.6 \mathrm{a}$ & $29.7 \mathrm{a}$ & $0.96 \mathrm{a}$ & $0.74 \mathrm{a}$ & $2.01 \mathrm{~b}$ & $1.89 \mathrm{a}$ \\
Astro & $8.2 \mathrm{a}$ & $9.0 \mathrm{a}$ & $29.4 \mathrm{a}$ & $31.3 \mathrm{a}$ & $37.2 \mathrm{a}$ & $32.2 \mathrm{a}$ & $0.98 \mathrm{a}$ & $0.81 \mathrm{a}$ & $2.27 \mathrm{a}$ & $1.98 \mathrm{a}$ \\
Cultivada & $6.8 \mathrm{~b}$ & $8.3 \mathrm{~b}$ & $25.7 \mathrm{c}$ & $27.4 \mathrm{c}$ & $33.1 \mathrm{a}$ & $32.6 \mathrm{a}$ & $0.87 \mathrm{a}$ & $0.81 \mathrm{a}$ & $1.71 \mathrm{~b}$ & $2.19 \mathrm{a}$ \\
Folha Larga & $8.1 \mathrm{a}$ & $9.5 \mathrm{a}$ & $27.4 \mathrm{~b}$ & $29.3 \mathrm{~b}$ & $36.2 \mathrm{a}$ & $33.4 \mathrm{a}$ & $0.95 \mathrm{a}$ & $0.83 \mathrm{a}$ & $2.18 \mathrm{a}$ & $2.14 \mathrm{a}$ \\
Giovana & $8.3 \mathrm{a}$ & $9.2 \mathrm{a}$ & $30.1 \mathrm{a}$ & $31.1 \mathrm{a}$ & $44.0 \mathrm{a}$ & $34.6 \mathrm{a}$ & $1.11 \mathrm{a}$ & $0.86 \mathrm{a}$ & $2.53 \mathrm{a}$ & $2.22 \mathrm{a}$ \\
LG Maia & $7.9 \mathrm{a}$ & $8.3 \mathrm{~b}$ & $28.2 \mathrm{~b}$ & $27.2 \mathrm{c}$ & $39.0 \mathrm{a}$ & $29.0 \mathrm{a}$ & $1.02 \mathrm{a}$ & $0.72 \mathrm{a}$ & $2.20 \mathrm{a}$ & $1.87 \mathrm{a}$ \\
Rococó & $7.3 \mathrm{~b}$ & $8.0 \mathrm{~b}$ & $26.0 \mathrm{c}$ & $26.6 \mathrm{c}$ & $35.1 \mathrm{a}$ & $29.5 \mathrm{a}$ & $0.92 \mathrm{a}$ & $0.73 \mathrm{a}$ & $1.85 \mathrm{~b}$ & $1.73 \mathrm{a}$ \\
\hline CV (\%) & 8.44 & 6.51 & 5.03 & 5.16 & 20.51 & 18.85 & 20.51 & 18.85 & 18.96 & 21.39 \\
F & 7.79 & 12.30 & 12.15 & 12.63 & 1.84 & 0.97 & 1.84 & 0.97 & 3.97 & 1.29 \\
\hline
\end{tabular}

Means followed by the same letter in the column do not differ statistically by the Scott-Knott test at $5 \%$ probability of error. 
behavior of arugula with organic and conventional fertilization.

Another important factor, in addition to production, is quality, because consumers appreciate organic products, not only because they do not use pesticides in their cultivation, but also because they believe in the higher nutritional value of these products (Srinieng and Thapa, 2018), which indicates the importance of the search for cultivars with higher nutrient and vitamin content. Arugula, for example, which was evaluated in the present work, is a vegetable rich in vitamin $\mathrm{C}$ and iron (Pignone, 1997) and the cultivars Folha Larga and Rococó presented the highest vitamin $\mathrm{C}$ contents, both in the summer and autumn (Table 2). It is noteworthy, however, that some environmental factors may affect the concentration of this vitamin in the leaves: when light, temperature and water availability, for example, are inadequate, they may lead to increased concentration of vitamin $\mathrm{C}$ (Antonious et al., 2009). Hall et al. (2014) and Nurzyńska-Wierdak (2015) found average values between 64 to $115 \mathrm{mg} .100 \mathrm{~g}^{-1}$. These values are higher than those found in this study, but different methodologies were used to obtain the concentration of this vitamin in arugula leaves, which may bring divergent results; therefore, the methods have to be standardized.

Iron content only differed statistically among cultivars in the fall, and the mean values were numerically lower than those found in the summer assay (Table 2), possibly due to the lower temperature, which induces a reduction in their absorption, as suggested by Bozokalfa et al. (2009). The authors stated that this trait may also be related to the genotype and the availability of this element in the soil. Iron availability in the soil was similar for all cultivars, but the response of each cultivar to the lowest temperature may have varied.

Nutritional properties are important for breeding programs, as diet plays a key role in promoting and maintaining health. Consumption of vegetables such as arugula, which is a source of vitamins and minerals, is a significant way of compensating for nutritional deficiency (Carvalho et al., 2006) and biofortification of vegetables is aimed at improving nutritional properties (Chomchan et al., 2017).

As for the reproductive phase, LG Maia and Astro flourished earlier than the other cultivars, with $50 \%$ of the plants flowered at 55 DAS (Figure 1). Apreciatta Folha Larga was the last cultivar to complete flowering, with 24 days longer than the earliest cultivars. The cultivars Rococó and Cultivada did not bud (did not produce seeds), possibly because of specific requirements, as some cultivars require flowering induction by low temperatures followed by long days and high temperatures (Mohamedien, 1994; Morales and Janick, 2002). Thus, the cultivars Rococó and Cultivada may require lower temperatures as well as different photoperiods under the local conditions of the experiment for induction, of flowering.

For silique length (SL), one thousand seed weight (TSW) and number of seeds per silique (NSeed.silique-1), Apreciatta Folha Larga and Folha Larga presented the lowest values (Table 3). Silique length is directly related to number of seeds per silique, because the larger the silique, the greater the potential number of seeds. These factors can also be determined by cultivar, since number of seeds per silique, according to Fazili et al. (2010), is genetically determined, with little influence on crop treatments, indicating the importance of choice of cultivar for better seed yield. There was no statistical difference in the parameters number of siliquae per plant and number of branches per plant.

For seed yield, LG Maia produced 3.6 times more seeds than the cultivar Folha Larga. Cultivars Astro, Giovana and

Table 2. Vitamin C and Iron content of leaves of different arugula cultivars produced in the organic system in a protected environment during summer and autumn.

\begin{tabular}{ccccc}
\hline \multirow{2}{*}{ Cultivar } & \multicolumn{2}{c}{ Vitamin C (mg ascorbic } & \multicolumn{2}{c}{ Ion content $\left(\mathrm{mg} . \mathrm{Kg}^{-1}\right)$} \\
\cline { 2 - 5 } & acid.100 $\mathrm{g}^{-1}$ sample $)$ & Summer & Fall & Fall \\
\hline Ágatha & $11.06 \mathrm{~b}$ & $9.4 \mathrm{~b}$ & $510.5 \mathrm{a}$ & $113.7 \mathrm{~b}$ \\
Apreciatta & $13.19 \mathrm{~b}$ & $12.3 \mathrm{a}$ & $760.0 \mathrm{a}$ & $222.0 \mathrm{a}$ \\
Folha Larga & & $13.9 \mathrm{a}$ & $653.0 \mathrm{a}$ & $143.7 \mathrm{~b}$ \\
Astro & $15.87 \mathrm{~b}$ & $12 \mathrm{a}$ & $706.0 \mathrm{a}$ & $112 \mathrm{~b}$ \\
Cultivada & $13.22 \mathrm{~b}$ & $13.8 \mathrm{a}$ & $874.5 \mathrm{a}$ & $124.2 \mathrm{~b}$ \\
Folha Larga & $19.05 \mathrm{a}$ & $8.2 \mathrm{~b}$ & $408.7 \mathrm{a}$ & $292.2 \mathrm{a}$ \\
Giovana & $18.67 \mathrm{a}$ & $7.2 \mathrm{~b}$ & $554.2 \mathrm{a}$ & $204.5 \mathrm{a}$ \\
LG Maia & $15.14 \mathrm{~b}$ & $14 \mathrm{a}$ & $578.7 \mathrm{a}$ & $258.0 \mathrm{a}$ \\
Rococó & $23.27 \mathrm{a}$ & 15 & 48.93 & 44.17 \\
\hline CV $(\%)$ & 26.46 & 10.06 & 0.92 & 2.98 \\
F & 3.42 & &
\end{tabular}

Means followed by the same letter in the column do not differ statistically by the Scott-Knott test at $5 \%$ probability of error.

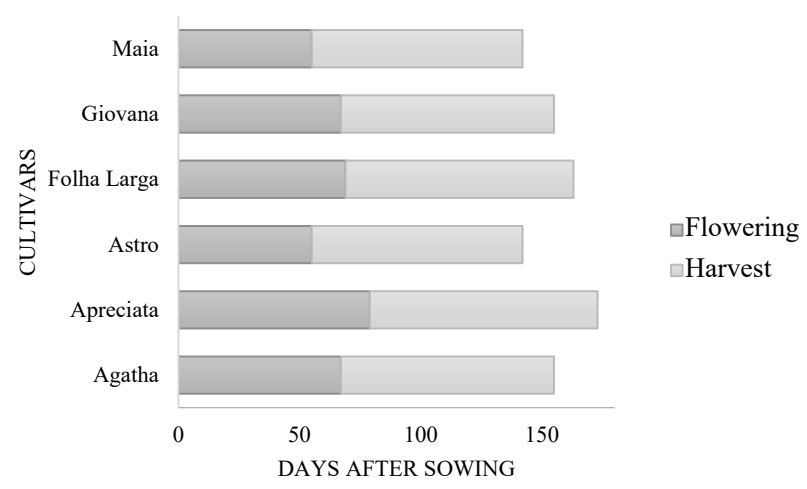

Figure 1. Flowering time of arugula cultivars and seed harvest in days after sowing. 
LG Maia had best performance, with similar results to those found by Lazzeri et al. (2004) with 2.0 t.ha $^{-1}$ (autumn) and 1.55 t.ha $^{-1}$ (summer) and Esiyok et al. (2013) with 1.3 t.ha1, both in the conventional system, which demonstrates the production potential in the organic system.

The difference in water content (Table 4) of seeds from different cultivars did not exceed the two percentage points, as advisable. This information is important for seed testing, as uniform water content is required for physiological potential assessments to achieve consistent results (Marcos-Filho, 1999).

The environment where the seeds were formed has great influence on germination, vigor and health. In this work, management and place of crop production were the same; however, there was a difference between cultivars: Ágatha and Giovana had the lowest results for germination and first germination count, indicating the influence of genotype on physiological potential, as reported by Marcos-Filho (2015).

The health test, performed immediately after harvest (Table 5), detected the incidence of fungi Alternaria sp, Aspergillus sp., Cladosporium sp., Penicillium sp. and Sclerotinia sp. LG Maia and Folha Larga presented a higher incidence of fungi, although not expressive, and this result did not interfere with germination, but it may reduce storage vigor or affect seedling development, since fungi Alternaria sp., Cladosporium sp. and Sclerotinia sp. are transmitted to seedlings (Vieira et al., 2015).

In this research, production occurred in a protected environment, a condition that provides lower humidity than

Table 3. Number of branches per plant $\left(\mathrm{NB}\right.$ plant $\left.{ }^{-1}\right)$, silique length (SL), total number of siliquae per plant (NSil plant ${ }^{-1}$ ), one thousand seed weight (TSW), number of seeds per silique (NSeed.silique ${ }^{-1}$ ) and seed yield (Y) of arugula cultivars conducted in an organic system.

\begin{tabular}{|c|c|c|c|c|c|c|}
\hline Cultivar & NB (g.plant ${ }^{-1}$ ) & $\mathrm{PH}(\mathrm{cm})$ & NSil.plant $^{-1 *}$ & TSW $(g)$ & NSeed.silique $^{-1}$ & $\mathrm{Y}\left(\mathrm{ha}^{-1}\right)^{*}$ \\
\hline Ágatha & $7.58 \mathrm{a}$ & $2.11 \mathrm{a}$ & $277.70 \mathrm{a}$ & $1.67 \mathrm{a}$ & $24.75 \mathrm{a}$ & $0.74 \mathrm{~b}$ \\
\hline Apreciatta Folha Larga & $6.90 \mathrm{a}$ & $1.48 \mathrm{~b}$ & $354.02 \mathrm{a}$ & $1.34 \mathrm{~b}$ & $17.54 \mathrm{~b}$ & $0.61 \mathrm{~b}$ \\
\hline Astro & $7.28 \mathrm{a}$ & $1.96 \mathrm{a}$ & $403.96 \mathrm{a}$ & $1.65 \mathrm{a}$ & $24.74 \mathrm{a}$ & $1.21 \mathrm{a}$ \\
\hline Folha Larga & $7.12 \mathrm{a}$ & $1.4 \mathrm{~b}$ & $344.59 \mathrm{a}$ & $1.23 \mathrm{~b}$ & $17.68 \mathrm{~b}$ & $0.46 \mathrm{c}$ \\
\hline Giovana & $6.61 \mathrm{a}$ & $2.07 \mathrm{a}$ & $355.80 \mathrm{a}$ & $1.80 \mathrm{a}$ & $23.76 \mathrm{a}$ & $1.11 \mathrm{a}$ \\
\hline LG Maia & $6.56 \mathrm{a}$ & $2.16 \mathrm{a}$ & $466.21 \mathrm{a}$ & $1.64 \mathrm{a}$ & $23.84 \mathrm{a}$ & $1.69 \mathrm{a}$ \\
\hline $\mathrm{CV}(\%)$ & 9.7 & 4.64 & 24.01 & 18.06 & 15.67 & 8.21 \\
\hline $\mathrm{F}$ & 0.6 & 28.91 & 1.04 & 4.79 & 8.04 & 7.89 \\
\hline
\end{tabular}

The averages followed by the same letter do not differ statistically from each other. The Scott-Knott Test was applied.

*Data transformed into $\sqrt{x}$.

Table 4. Water content, germination test $(\mathrm{G})$ and first germination count $\left(1^{\text {st }} \mathrm{GC}\right)$ of seeds of different freshly harvested arugula cultivars.

\begin{tabular}{cccc}
\hline Cultivar & Water content $(\%)$ & $\mathrm{G}(\%)^{*}$ & $1^{\text {st }} \mathrm{GC}(\%)^{*}$ \\
\hline Ágatha & 7.23 & $91 \mathrm{c}$ & $89 \mathrm{c}$ \\
Apreciatta Folha & 7.13 & $100 \mathrm{a}$ & $100 \mathrm{a}$ \\
Larga & 7.17 & $98 \mathrm{a}$ & $96 \mathrm{a}$ \\
Astro & 6.70 & $99 \mathrm{a}$ & $98 \mathrm{a}$ \\
Folha Larga & 6.81 & $95 \mathrm{~b}$ & $94 \mathrm{~b}$ \\
Giovana & 6.51 & $98 \mathrm{a}$ & $97 \mathrm{a}$ \\
LG Maia & - & 1.2 & 2.4 \\
\hline CV $(\%)$ & - & 8.07 & 9.68 \\
F & &
\end{tabular}

*Means followed by the same letter in the column do not differ statistically by the Scott-Knott test at $5 \%$ probability of error.

*Data transformed into $\sqrt{x}$.
Table 5. Incidence of fungi (\%) Alternaria $s p \quad(\mathrm{Al})$ Aspergillus sp (As), Cladosporium sp (Cl), Penicillium $s p(\mathrm{Pe})$ and Sclerotinia $s p(\mathrm{Sc})$ in seeds of different cultivars of freshly harvested arugula.

\begin{tabular}{cccccc}
\hline \multirow{2}{*}{ Cultivar } & \multicolumn{5}{c}{ Fungal incidence (\%) } \\
\cline { 2 - 6 } & $\mathrm{Al}$ & $\mathrm{As}$ & $\mathrm{Cl}$ & $\mathrm{Pe}$ & $\mathrm{Sc}$ \\
\hline Ágatha & $0.5 \mathrm{a}$ & $1.0 \mathrm{a}$ & $4.0 \mathrm{a}$ & $1.5 \mathrm{a}$ & $0.0 \mathrm{a}$ \\
$\begin{array}{c}\text { Apreciatta Folha } \\
\text { Larga }\end{array}$ & $0.0 \mathrm{a}$ & $0.0 \mathrm{a}$ & $2.5 \mathrm{a}$ & $0.5 \mathrm{a}$ & $0.0 \mathrm{a}$ \\
Astro & $1.0 \mathrm{a}$ & $1.5 \mathrm{a}$ & $1.0 \mathrm{a}$ & $1.0 \mathrm{a}$ & $0.0 \mathrm{a}$ \\
Folha Larga & $6.5 \mathrm{~b}$ & $2.0 \mathrm{a}$ & $6.5 \mathrm{~b}$ & $1.0 \mathrm{a}$ & $0.0 \mathrm{a}$ \\
Giovana & $2.0 \mathrm{a}$ & $0.0 \mathrm{a}$ & $1.0 \mathrm{a}$ & $0.0 \mathrm{a}$ & $0.0 \mathrm{a}$ \\
LG Maia & $9.0 \mathrm{~b}$ & $0.0 \mathrm{a}$ & $9.0 \mathrm{~b}$ & $4.5 \mathrm{~b}$ & $1.0 \mathrm{a}$ \\
\hline CV (\%) & 93.56 & 146.72 & 83.75 & 138.15 & 482.51 \\
F & 6.23 & 2.35 & 3.67 & 2.43 & 0.94 \\
\hline
\end{tabular}

The means followed by the same letter do not differ statistically by the ScottKnott test at 5\% probability level. 
in the open field, and, consequently, it may have contributed to the low incidence of fungi. But as seeds can act as a vehicle for fungal dissemination in disease-free areas, their control and the search for alternative treatments are important, since the legislation that regulates the production of organic seeds (Brasil, 2011), does not allow the use of chemicals for phytosanitary control for the purpose of seed treatment.

During storage, there was a reduction in seed germination and vigor, in general. However, Apreciatta Folha Larga, Astro and LG Maia presented higher values for germination, first germination count, germination speed index (GSI) and emergence in comparison to the other cultivars, and they did not differ from one another (Table 6). Folha Larga showed reduced germination and vigor in comparison to other cultivars during storage, possibly because of the increase in associated fungi, especially Penicillium sp., and genetic factors, as suggested by Suma et al. (2013). Moreover, the seeds were stored in paper bags, which allows the exchange of gases and water with the environment; therefore, it may have contributed to the reduction of germination and increase of fungi.

Regarding the incidence of fungi after storage, only Penicillium sp. and A. alternata were found to show differences between cultivars (Table 7). The seeds of the cultivar Astro presented lower incidence of Penicillium sp. and its germination, first germination count, GSI and emergence values were higher. LG Maia increased the percentage of fungi after storage; however, its initial germination contributed to maintaining vigor.

In the production of brassica seeds, it is recommended that in flowering and seed maturation, the environment is dry and free from precipitation, in order to obtain high yields of seeds with high vigor (Contreras et al., 2014). When the location cannot be chosen, a protected environment is an alternative. The results of this research showed that arugula seeds can be produced in the organic system, but water content before storage needs to be adjusted and airtight packaging needs to be used, allowing producers and companies to produce arugula seeds of acceptable quality in alternative production systems in protected environments, as long as farmers use the appropriate cultivar for each region.

\section{Conclusions}

The cultivars Giovana, Ágatha and Astro have good productive performance in the organic system.

Organic arugula seeds can be produced with high values for yield, germination, vigor and health in a protected environment. The cultivars Astro and LG Maia stand out in the production of seeds with high germination, vigor and health in the organic system.
Table 6. Germination $(\mathrm{G}), 1^{\text {st }}$ germination count $\left(1^{\text {st }} \mathrm{GC}\right)$, emergence speed index (ESI) and emergence (E) of arugula cultivars after cold/dry storage for one year.

\begin{tabular}{|c|c|c|c|c|}
\hline Cultivar & $\mathrm{G}(\%)$ & $1^{\text {st }} \mathrm{GC}(\%)$ & ESI & $\mathrm{E}(\%)$ \\
\hline Ágatha & $87 \mathrm{~b}$ & $87 \mathrm{~b}$ & $11.9 \mathrm{~b}$ & $78.5 \mathrm{~b}$ \\
\hline $\begin{array}{c}\text { Apreciatta } \\
\text { Folha Larga }\end{array}$ & $94 \mathrm{a}$ & $93 \mathrm{a}$ & $12.9 \mathrm{a}$ & $91.5 \mathrm{a}$ \\
\hline Astro & $93 \mathrm{a}$ & $92 \mathrm{a}$ & $13.9 \mathrm{a}$ & $95.5 \mathrm{a}$ \\
\hline Folha Larga & $81 \mathrm{~b}$ & $80 \mathrm{~b}$ & $10.8 \mathrm{~b}$ & $76.0 \mathrm{~b}$ \\
\hline Giovana & $85 \mathrm{~b}$ & $84 \mathrm{~b}$ & $12.0 \mathrm{~b}$ & $86.0 \mathrm{a}$ \\
\hline LG Maia & $94 \mathrm{a}$ & $94 \mathrm{a}$ & $12.7 \mathrm{a}$ & $92.5 \mathrm{a}$ \\
\hline CV (\%) & 3.1 & 5.7 & 8.1 & 7.6 \\
\hline F & 3.99 & 4.94 & 4.61 & 5.84 \\
\hline
\end{tabular}

Means followed by the same letter in the column do not differ statistically by the Scott-Knott test at $5 \%$ probability of error.

Table 7. Fungal incidence (\%) in seeds of arugula cultivars after storage in a dry chamber for one year.

\begin{tabular}{ccc}
\hline \multirow{2}{*}{ Cultivar } & \multicolumn{2}{c}{ Fungal incidence $(\%)$} \\
\cline { 2 - 3 } & Penicillium sp. & Alternaria alternata \\
\hline Ágatha & $12.5 \mathrm{a}$ & $0.5 \mathrm{a}$ \\
Apreciatta Folha Larga & $33.5 \mathrm{~b}$ & $1.0 \mathrm{a}$ \\
Astro & $23.5 \mathrm{a}$ & $5.5 \mathrm{~b}$ \\
Folha Larga & $59.0 \mathrm{c}$ & $0.0 \mathrm{a}$ \\
Giovana & $35.5 \mathrm{~b}$ & $1.0 \mathrm{a}$ \\
Maia & $30.0 \mathrm{~b}$ & $2.0 \mathrm{a}$ \\
\hline CV (\%) & 37.40 & 103.92 \\
F & 6.56 & 5.28 \\
\hline
\end{tabular}

Means followed by the same letter in the column do not differ statistically by the Scott-Knott test at $5 \%$ probability of error.

\section{References}

ANTONIOUS, G.F.; BOMFORD, M.; VINCELLI, P. Screening brassica species for glucosinolate content. Journal of Environmental Science and Health, Part B: pesticides, foods contaminants and agricultural wastes, v.44, n.3, p.311-316, 2009. https://www.ncbi. nlm.nih.gov/pubmed/19280485

BOZOKALFA, M.K.; YAGMUR, B.; ILBI, H.; ESIYOK, D.; KAVAK, K. Genetic variability for mineral concentration of Eruca sativa L. and Diplotaxis tenuifolia L. accessions. Crop Breeding and Applied Biotechnology, v.9, n.4, p.372-381, 2009. https:// www.researchgate.net/publication/40892927_Genetic_variability_ for_mineral_concentration_of_Eruca_sativa_L_and_Diplotaxis_ tenuifolia_L_accessions 
BRASIL. Ministério da Agricultura, Pecuária e Abastecimento. Regras para análise de sementes. Ministério da Agricultura, Pecuária e Abastecimento. Secretaria de Defesa Agropecuária. Brasília: MAPA/ACS, 2009. 395p. http:// www.agricultura.gov.br/ arq_editor/file/2946_regras_analise_sementes.pdf

BRASIL. Ministério da Agricultura, Pecuária e Abastecimento. Manual de análise sanitária de sementes. Ministério da Agricultura, Pecuária e Abastecimento. Secretaria de Defesa Agropecuária. Brasília: Mapa/ ACS, 2009. 200p. http://www.agricultura.gov.br/assuntos/insumosagropecuarios/insumos-agricolas/sementes-e-mudas/publicacoessementes-e-mudas/manual-de-analise-sanitaria-de-sementes

BRASIL. Instrução normativa $\mathrm{n}^{\circ} 38$, de 2 de agosto de 2011. Diário Oficial da União, Ministério da Agricultura e Pecuária, Brasília, DF, 3 ago. 2011, Seção 1. http://sistemasweb.agricultura.gov.br/ sislegis/action/detalhaAto.do? method $=$ gravarAtoPDF\&tipo $=I N-$ M\&numeroAto $=00000038 \&$ seqA to $=000 \&$ valorAno $=2011 \&$ orgao $=$ MAPA $\& \operatorname{codTipo}=\&$ desItem $=\&$ desItemFim $=$

CARVALHO, C.R.L.; MANTOVANI, D.M.B.; CARVALHO, P.R.N.; MORAES, R.M.M. Análises químicas de alimentos. Campinas: ITAL, 1990. 121p.

CHOMCHAN, R.; SIRIPONGVUTIKORN, S.; PUTTARAK, P. Selenium bio-fortification: an alternative to improve phytochemicals and bioactivities of plant foods. Functional Foods in Health and Disease, v.7, n.4, p.263-279, 2017. https://pdfs.semanticscholar. org/21 ce/4918d9cc04b79587b6abb32e0d585d35ba17.pdf?_ $\mathrm{ga}=2.268870449 .1924839682 .1571147453-584067448.157114745$

CONTRERAS, S.; FARÍAS, A.; NASCIMENTO, W.M. Produção de sementes de Brassica oleraceae. In: NASCIMENTO, W.M. (ed.). Hortaliças: tecnologia de produção de sementes. Brasília: EMBRAPA Hortaliças, 2014. p.45-77.

CARVALHO, P.G.B.; MACHADO, C.M.M.; MORETTI, C.L.; FONSECA, M.E.N. Hortaliças como alimentos úteis. Horticultura Brasileira, v.24, n.4, p.397-404, 2006. http://dx.doi.org/10.1590/ S0102-05362006000400001

EMPRESA BRASILEIRA DE PESQUISA AGROPECUÁRIA. Sistema brasileiro de classificação de solos. 2. ed. Rio de Janeiro: Centro Nacional de Pesquisa de Solos, 2006. 306p.

ESIYOK, D.; BOZOKALFA, M.K.; KAVAK, S.; UGUR, A. Seed yield, quality and plant characteristics changes of rocket salad (Eruca sativa Mill.) under different nitrogen sources and vegetation periods. Süleyman Demirel Üniversitesi Ziraat Fakültesi Dergisi, v.8, n.1, p.5359, 2013. https://dergipark.org.tr/en/download/article-file/308699

FAZILI, I.S.; MUZAIN, M.; AHMAD, S.; JAMAL, A.; KHAN, J.S.; ABDIN, M.Z. Interactive effect of sulfur and nitrogen on growth and yield attributes of oilseed crops (Brassica campestris L. and Eruca sativa Mill.) differing in yield potential. Journal of Plant Nutrition, v.33, n.8, p.1216-1228, 2010. https://www.tandfonline.com/doi/ abs/10.1080/01904161003765745

FILGUEIRA, F.A.R. Novo manual de olericultura: agrotecnologia moderna na produção e comercialização de hortaliças. 3. ed. rev. e ampl. Viçosa: UFV, 2008. 412p.
HALL, M.K.D.; JOBLING, J.J.; ROGERS, G.S.Effect of nitrogen supply and storage temperature on vitamin $\mathrm{c}$ in two species of baby leaf rocket, and the potential of these crops for a nutrient claim in Australia. Journal of Plant Nutrition, v.38, n.2, p.246-259, 2014. https://www.tandfonline. com/doi/abs/10.1080/01904167.2013.873465?journalCode=lpla20

LAZZERI, L.; ERRANI, M.; LEONI, O.; VENTURI, G. Eruca sativa spp. oleifera: a new non-food crop. Industrial Crops and Products, v.20, n.1, p.67-73, 2004. https://www.researchgate.net/publication/229205148_ Eruca_sativa_spp_oleifera_A_new_non-food_crop

MARCOS-FILHO, J. Testes de vigor: importância e utilização In: KRZYZANOWSKI, F.C.; VIEIRA, R.D.; FRANÇA-NETO, J.B. (ed.). Vigor de sementes: conceitos e testes. Londrina: ABRATES, 1999. p.1.1-1.21.

MARCOS-FILHO, J. Fisiologia de sementes de plantas cultivadas. 2 ed. Londrina: ABRATES, 2015. 660p.

MAGUIRE, J.D. Speed of germination-aid in relation evaluation for seedling emergence vigor. Crop Science, v.2, p.176-177, 1962.

Ministério da Agricultura, Pecuária e Abastecimento (MAPA). Cadastro nacional de produtores orgânicos. Available on $<\mathrm{http} / /$ www.agricultura.gov.br/assuntos/sustentabilidade/organicos/cadastronacional-produtores-organicos $>$. Accessed on: October $15^{\text {th }}, 2018$.

MORALES, M.; JANICK, J. Arugula: a promising specialty leaf vegetable. In: JANICK, J.; WHIPKEY, A. (ed.). Trends in new crops and new uses. Alexandria: ASHS Press, 2002. p.418-423.

MOHAMEDIEN, S. Rocket cultivation in Egypt. In: PADULOSI, S. (ed.). Rocket genetic resources network. International Plant Genetic Resources Institute, 1994. p.61-62.

NASCIMENTO, W.M. Sementes entraves na produção orgânica. 2013. Available on $<$ https://ciorganicos.com.br/biblioteca/sementesentraves-na-producao-organica/>. Accessed on: November $8^{\text {th }}, 2018$.

NOGUEIRA, A.R. Manual de laboratório: solo, água, nutrição vegetal, nutrição animal e alimentos. São Carlos: EMBRAPA Pecuária Sudeste, 2005. 334p.

NURZYŃSKA-WIERDAK, R. Biological value of Eruca Sativa mill. leaves under the different plant nutrition by nitrogen and potassium. Acta Scientiarum Polonorum. Hortorum Cultus, v.14, n.5, p.41-53, 2015. https://www.researchgate.net/publication/283865273 Biological value_of_Eruca_sativa_Mill_Leaves_under_the_different_plant_ nutrition by nitrogen and potassium

OLIVEIRA, E.Q.; SOUZA, R.J.; CRUZ, M.C.M.; MARQUES, V.B.; FRANÇA, A.C. Produtividade de alface e rúcula, em sistema consorciado, sob adubação orgânica e mineral. Horticultura Brasileira, v.28, n.1, p.36-40, 2010. http://www.scielo.br/scielo.php?script=sci_ arttext\&pid=S0102-05362010000100007\&lng=en\&nrm=iso

PIGNONE, D. Present status of rocket genetic resources and conservation activies. In: PADULOSI, S.; PIGNONE, D. Rocket: a mediterranean crop for the world. Plant Genetic Resources Institute, 1997.

REGHIN, M.Y.; OTTO, R.F.; OLINIK, J.R.; JACOBY, C.F.S. Efeito do espaçamento e do número de mudas por cova na produção de rúcula nas estações de outono e inverno. Ciência e Agrotecnologia, v.29, n.5, p.953959, 2005. http://dx.doi.org/10.1590/S1413-70542005000500006 
SRINIENG, S.; THAPA, G.B. Consumer's perception of environmental and health benefits, and consumption of organic vegetables in Bangkok. Agricultural and Food Economics, v.6, n.5, p.1-17, 2018. https://link. springer.com/article/10.1186/s40100-018-0100-x

SUMA, A.; SREENIVASAN, K.; SINGH, A.K.; RADHAMANI, $\mathrm{J}$. Role of relative humidity in processing and storage of seeds and assessment of variability in storage behaviour in Brassica spp. and Eruca sativa. The Scientific World Journal, v.2013, p.1-10, 2013. https://www.ncbi.nlm.nih.gov/pmc/articles/PMC3893012/
TORRES, S.B.; BALBINO, D.A.D.; SANTOS, W.G.N.; NOGUEIRA, N.W.; FREITAS, R.M.O.; LEITE, M.S. Avaliação do vigor de sementes de rúcula pela atividade respiratória. Horticultura Brasileira, v.34, n.4, p.561-564, 2016. http://www.scielo.br/scielo.php?script=sci_ arttext\&pid=S0102-05362016000400561\&lng=en\&nrm=iso

VIEIRA, J.F.; OLIVEIRA, S.; ZANATTA, Z.C.N. Physiological and phytosanitary potential of rocket seeds. Ciência Rural, v.45, n.2, p.200-205, 2015. http://www.scielo.br/scielo.php?script=sci_ arttext\&pid=S0103-84782015000200200\&lng=en\&nrm=iso 